\title{
PEMBATALAN PERJANJIAN JUAL BELI SECARA SEPIHAK OLEH KONSUMEN DI PT. RESTU PROPERTY
}

\author{
Made Rama Prawira, Fakultas Hukum Universitas udayana, e-mail : \\ prawirarama37@yahoo.com \\ I Wayan Novy Purwanto, Fakultas Hukum Universitas Udayana, e-mail : \\ novy_purwanto@unud.ac.id
}

doi: https://doi.org/10.24843/KS.2020.v08.i12.p05

\begin{abstract}
ABSTRAK
Tujuan penelitian ini adalah untuk mengetahui pelaksanaan perjanjian jual beli rumah pada PT. Restu Property dan mengetahui akibat hukum pembatalan perjanjian jual beli rumah secara sepihak oleh konsumen di PT. Restu Property. Metode penelitian hukum yang digunakan dalam penelitian ini adalah jenis penelitian hukum empiris. Digunakannya jenis penelitian ini yaitu untuk melakukan pengkajian terhadap pelaksanaan perjanjian jual beli rumah pada PT. Restu Property dan mengkaji akibat hukum pembatalan perjanjian jual beli rumah secara sepihak oleh konsumen di PT. Restu Property. Pendekatan penelitian ini yakni menggunakan pendekatan perundang-undangan dan pendekatan fakta. Pelaksanaan perjanjian jual beli rumah pada PT. Restu Property tahapannya meliputi pembayaran atau disebut dengan istilah booking fee atau tanda jadi, pemilihan desain bangunan, menentukan cara pembayaran yang dapat dilakukan dengan cara tunai atau dengan kredit pemilikan rumah, pembayaran uang muka atau down payment, dilanjutkan dengan pembangunan rumah. Setelah rumah selesai dibangun dilakukan serah terima rumah dan pembuatan Akta Jual Beli, berdasarkan hal tersebut apabila pembayaran dilakukan dengan kredit maka pencairan kredit pemilikan rumah tersebut dapat dilakukan. Sedangkan akibat hukum terhadap pembatalan perjanjian sepihak yang dilakukan oleh konsumen kepada PT. Restu Property adalah perjanjian dapat dibatalkan tanpa kewajiban bagi pihak developer untuk mengembalikan uang muka atau down payment yang telah dibayarkan oleh konsumen.
\end{abstract}

Kata Kunci : Pembatalan, Perjanjian, Jual Beli dan Sepihak.

\begin{abstract}
The purpose of this study was to determine the implementation of the house sale and purchase agreement at PT. Restu Property and know the legal consequences of the cancellation of the house sale and purchase agreement unilaterally by consumers at PT. Restu Property. The legal research method used in this study is a type of empirical legal research. The use of this type of research is to conduct an assessment of the implementation of the house sale and purchase agreement at PT. Restu Property and examine the legal consequences of the cancellation of the house sale and purchase agreement unilaterally by consumers at PT. Restu Property. This research approach is to use a fact approach and a statutory approach.implementation of the house sale and purchase agreement at PT. Restu Properti, the stages include payment or what is called a booking fee or sign, choosing a building design, determining the method of payment that can be made in cash or in installments, down payment or down payment, by building a house. After the house is completed, the handover of the house is carried out and the making of a Sale and Purchase Deed, based on this the payment must be made by credit so that the disbursement of the mortgage can be made. Meanwhile, the legal consequences for the cancellation of unilateral agreements made by consumers to PT. Restu Property is an agreement that can be canceled without obligation for the developer to return the down payment or down payment that has been made by the consumer.
\end{abstract}


Keywords: Cancellation, Agreement, Sale and Purchase and Unilateral.

\section{Pendahuluan}

\subsection{Latar Belakang}

Ketentuan Pasal 28 H ayat (1) Undang-Undang Dasar Negara Republik Indonesia Tahun 1945 (selanjutnya disebut dengan UUD NRI 1945) menyatakan bahwa "setiap orang berhak hidup sejahtera lahir batin, bertempat tinggal dan mendapatkan lingkungan hidup yang baik dan sehat". Berdasarkan ketentuan pasal tersebut dapat diketahui bahwa salah satu unsur pokok kesejahteraan rakyat adalah terpenuhinya kebutuhan akan perumahan, dimana rumah yang merupakan kebutuhan dasar bagi setiap Warga Negara Indonesia. Setiap orang berhak hidup sejahtera lahir dan batin, bertempat tinggal, dan mendapatkan lingkungan yang baik dan sehat, yang merupakan kebutuhan dasar manusia.

Sehubungan dengan itu, dalam ketentuan Pasal 1 Angka 2 Undang-Undang Nomor 1 tahun 2011 tentang Perumahan dan Kawasan Permukiman (selanjutnya disebut dengan (UU Perumahan dan Kawasan Pemukiman) memberi pengertian mengenai "perumahan adalah kumpulan rumah sebagai bagian dari pemukiman, baik perkotaan maupun perdesaan, yang dilengkapi dengan prasarana, sarana, dan utilitas umum sebagai hasil upaya pemenuhan rumah yang layak huni". Sedangkan dalam Pasal 1 Angka 5 undang-undang ini menentukan bahwa "pemukiman adalah bagian dari lingkungan hunian yang terdiri atas lebih dari satu perumahan yang mempunyai prasarana, sarana, utilitas umum, serta mempunyai penunjang kegiatan fungsi lain di kawasan perkotaan atau kawasan perdesaan.

Harga tanah dan bahan bangunan yang semakin meningkat, membuat kepemilikan rumah sangat berat bagi sebagian orang. Untuk itu membeli rumah secara kredit, yang biasanya disebut Kredit Kepemilikan Rumah (selanjutnya disingkat KPR), menjadi pilihan cara memiliki rumah yang terjangkau bagi banyak orang. Penjualan rumah dengan cara KPR sering digunakan oleh pengembang perumahan (Developer) yang menawarkan beberapa unit rumah kepada calon pembeli. "Seringkali rumah yang ditawarkan oleh Developer dalam kondisi belum terbangun, yaitu masih berupa kaplingkapling tanah. Pembangunan baru dimulai setelah ada calon pembeli yang memesan rumah dengan membayar uang muka atau DP (Down Payment). Sistem tersebut dinamakan Pre Project Selling yaitu cara penjualan properti oleh Developer sebelum bangunan fisik selesai dibangun". ${ }^{1}$

Jual beli menurut Kitab Undang-Undang Hukum Perdata (selanjutnya disingkat KUHPerdata) adalah suatu perjanjian bertimbal balik dalam mana pihak yang satu (penjual) berjanji untuk menyerahkan hak milik atas suatu barang, sedangkan pihak yang lainnya (pembeli) berjanji untuk membayar harga yang terdiri atas sejumlah uang sebagai imbalan dari perolehan hak milik tersebut ${ }^{2}$.

Menurut ketentuan yang diatur dalam Keputusan Menteri Negara Perumahan Rakyat Nomor 09/KTPS/1995 tanggal 23 Juni 1995 tentang Pedoman Pengikatan Jual Beli Rumah, dinyatakan bahwa ada dua pihak dalam perjanjian yaitu :

1 Heryy, Kamaroesid, Tata Cara Pendirian dan Pengelolaan Badan Usaha Milik Negara, (Mitra Wacana Media, Bogor, 2016), 34.

2 Anonim. Apakah Kuasa Dalam PPJB Termasuk Dalam Kategori Kuasa Mutlak?. http://m.propertykita.com/ (diakses September 22 ,2020). 
1.Pihak Perusahaan Pembangunan Perumahan dan Permukiman atau Developer atau Pelaku Usaha yang bertindak sebagai penjual rumah; dan

2.Pihak Konsumen selaku pembeli rumah.

Sehubungan dengan pembatalan jual beli rumah di PT. Restu Property, ketentuan Pasal 1266 KUHPerdata menyiratkan bahwa "suatu syarat batal dianggap selalu dicantumkan dalam perjanjian apabila salah satu pihak tidak melaksanakan kewajibannya". Dengan kata lain bahwa syarat batal dianggap selalu dicantumkan dalam persetujuan yang timbal balik, andai kata salah satu pihak tidak memenuhi kewajibannya.

Syarat batal ini merupakan suatu batasan, "dimana jika salah satu pihak tidak melaksanakan kewajibannya dalam perjanjian (wanprestasi), maka pihak yang lain dalam perjanjian itu dapat membatalkan perjanjian secara sepihak tanpa persetujuan pihak yang melakukan wanprestasi. Klausula semacam ini dianggap selalu ada dalam setiap perjanjian sehingga meskipun suatu perjanjian tidak menentukannya dalam bunyi pasal-pasalnya, prinsip ini tetap berlaku".3

Dalam prakteknya, membuat surat perjanjian sering dimasukkan klausula bahwa "jika salah satu pihak tidak melaksanakan kewajibannya, maka pihak lain dapat membatalkan perjanjian."Sebenarnya klausul semacam itu tidak perlu dimasukkan ke dalam perjanjian karena hukum perdata telah menerapkan prinsip umum dalam perjanjian berupa syarat batal". ${ }^{4}$ Tetapi keberlakuan prinsip ini tidak serta merta. Meskipun syarat batal dianggap selalu berlaku pada semua perjanjian, namun batalnya perjanjian itu tidak dapat terjadi begitu saja, melainkan harus diminta pembatalannya kepada pengadilan. Pihak yang menyatakan pihak lainnya wanprestasi harus mengajukan pembatalan kepada pengadilan. Tanpa adanya putusan pengadilan yang menyatakan bahwa salah satu pihak telah wanprestasi dan karenanya perjanjian dibatalkan, maka dapat dikatakan tidak ada perjanjian yang batal.

Penelitian sebelumnya yang dilakukan oleh Ida Ayu Putu Krisna Yanthi dan I Wayan Novy Purwanto yang berjudul Analisis Hukum Pembatalan Perjanjian Sewa Menyewa Kebaya Secara Sepihak Di Kota Denpasar menunjukkan adanya persamaan dan perbedaan. Persamaannya terletak pada pembatalan sepihak terhadap suatu perjanjian sedangkan perbedaannya terletak pada bentuk dan obyek dari perjanjian tersebut. Bentuk perjanjiannya adalah perjanjian sewa menyewa sedangkan bentuk perjanjian dalam penelitian ini adalah perjanjian jual beli. Demikian pula obyek dalam penelitian sebelumnya adalah kebaya (benda bergerak) sedangkan dalam penelitian ini adalah rumah (benda tidak bergerak). Sehingga penelitian ini memiliki orisinalitas yang membedakan dengan penelitian sebelumnya.

\subsection{Rumusan Masalah}

1.2.1. Bagaimanakah pelaksanaan perjanjian jual beli rumah pada PT. Restu Property?

1.2.2. Bagaimanakah akibat hukum pembatalan perjanjian jual beli rumah secara sepihak oleh konsumen di PT. Restu Property?

3 Komang Bagus Try Permana dan A.A. Istri Ari Atu Dewi." Tugas- Tugas Badan Perlindungan Konsumen Nasional." Kertha Semaya: Journal Ilmu Hukum 2, no.1 (2017), 5.

4 Liberty Sinaga dan I.B Surya Dharma Jaya. " Pembatalan Perjanjian Jual Beli Online Secara Sepihak Oleh Lazada.CO.ID. “Kerta Semaya: Journal Ilmu Hukum 2, no.2 (2014), 6. 


\subsection{Tujuan Penulisan}

Penulisan ini bertujuan untuk mengetahui pelaksanaan perjanjian jual beli rumah pada PT. Restu Property dan mengetahui akibat hukum pembatalan perjanjian jual beli rumah secara sepihak oleh konsumen di PT. Restu Property. Pembatalan perjanjian yang diatur dalam KUHPerdata dan akibat hukum terhadap para pihak dalam perjanjian apabila terjadi pembatalan perjanjian.

\section{Metode Penelitian}

Penelitian hukum merupakan "suatu proses yang ditempuh untuk menemukan guna dapat menjawab isu-isu hukum yang ada". ${ }^{5}$ Metode penelitian ini menggunakan jenis penelitian hukum empiris. Pendekatan yang digunakan dalam penelitian ini yaitu pendekatan peraturan perundang-undangan, pendekatan konsep dan pendekatan fakta. Sumber data yang digunakan yaitu sumber data primer berupa hasil wawancara dengan responden yaitu pihak pembeli rumah di PT. Restu Property dan pihak penjual rumah. Sedangkan data sekunder berupa bahan-bahan hukum seperti Kitab UndangUndang Hukum Perdata. Teknik pengumpulan data dalam penelitian ini dilakukan dengan cara observasi di PT. Restu Property dan di Kantor Notaris dan wawancara dengan pihak penjual rumah (produsen) dan pihak pembeli rumah (konsumen). Selanjutnya, dalam teknik pengolahan dan analisis data menggunakan analisis deskriptif analitis yaitu menguraikan fakta-fakta yang terjadi di PT. Restu Property dan menganalisis akibat hukum pembatalan perjanjian jual beli rumah secara sepihak oleh konsumen di PT. Restu Property.

\section{Hasil dan Pembahasan}

\subsection{Pelaksanaan Perjanjian Jual Beli Rumah Pada PT. Restu Property}

Pihak pembeli atau konsumen harus memperhatikan langkah-langkah sebelum membeli rumah atau property dari developer khususnya apabila konsumen telah menyepakati harga transaksi dengan penjual atau developer. Pada dasarnya ada 4 (empat) tahap yang harus dilakukan sebelum melakukan transaksi jual beli oleh pejabat yang berwenang:

a. Pengecekan awal oleh calon pembeli

Pengecekan awal disini adalah pengecekan yang dilakukan sebelum konsumen melakukan kesepakatan jual beli. Konsumen dapat meminta copy sertifikat dan copy pembayaran PBB untuk mengetahui siapa pemilik dari property atau rumah tersebut. Bila bukti kepemilikan masih berupa PPJB maka sebaliknya konsumen mengecek ke kantor developer untuk mengetahui apakah penjual adalah pemilik terkini dari unit rumah yang dimaksud. Apabila penjual bukanlah pemilik terkini namun orang yang memegang kuasa jual/kuasa pengoperan hak, maka sebaiknya konsumen melakukan pengecekan ke Notaris yang membuatkan surat kuasa jual/surat kuasa pengoperan hak itu terkait dengan validitas dari kuasa tersebut. ${ }^{6}$

b. Penandatanganan kesepakatan jual beli diikuti dengan pembayaran tanda jadi.

5 Marzuki, Peter Mahmud, Penelitian Hukum Edisi Revisi, (Predana Media Group, Jakarta,2010), 35.

6 Realty Real Estate Agents, Apa Yang Harus Anda Perhatikan Ketika Sudah Setuju Dengan Harga Property, http://www.kebayoranrealty.com/ (diakses September 22,2020). 
Setelah konsumen melakukan pengecekan awal maka langkah selanjutnya adalah "meminta Notaris/PPAT untuk mengecek keaslian sertipikat tanah. Disini Notaris akan meminta setipikat asli untuk di cek ke Kantor Pertanahan. Namun sebelum pengecekan dilakukan ke Notaris tentunya developer akan meminta diikat dulu dengan tanda jadi, sehingga disinilah pentingnya membuat kesepakatan jual beli".7

c. "Pengecekan oleh PPAT jikalau bukti kepemilikan sudah dalam sertifikat. Apabila masih PPJB, maka pengecekan developer dilakukan pada pengecekan awal.

d. Penandatanganan Akta Jual Beli/Pengalihan Hak di developer". 8

Menurut pendapat bapak I Wayan Restu Yudha selaku manajer PT.Restu Property (berdasarkan wawancara pada hari Kamis tanggal 15 September 2020 pukul 10.30 Wita), menyatakan bahwa tidak semua orang memahami atau mengetahui prosedur jual beli rumah di developer (pengembang). Setelah ada kesepakatan antara pembeli dan penjual rumah barulah pihak developer membangun rumah yang dipesan oleh pihak konsumen. Adapun tahapan pelaksanaan perjanjian yang dilakukan saat konsumen membeli rumah kepada PT.Restu Property yaitu :

1. Booking Fee

Setelah PT.Restu Property memasarkan unit rumah dengan cara melakukan penyebaran pamphlet, flyer, baliho dan lain-lain, maka konsumen dapat melihat dan mengecek lokasi, unit, harga, dan lain-lain yang sudah ditentukan. Setelah konsumen mulai mengerti dan berminat maka konsumen dapat memberikan booking fee atau tanda jadi yaitu dengan cara menyetorkan sejumlah uang sebagai tanda keseriusan dari konsumen. Tanda jadi yang ditentukan oleh PT.Restu Property adalah 10\% dari harga rumah. Setelah membayar tanda jadi, konsumen dan pihak developer membuat PPJB.

2. Desain Produk (Bangunan)

Setelah konsumen memilih kavling yang tersedia, maka konsumen akan diberikan informasi mengenai desain bangunannya.

3. Cara Pembayaran

Setelah adanya uang muka (DP), maka pembangunan rumah segera mulai dilaksanakan. Pembayaran rumah dapat dilakukan dengan cara cash (tunai), dengan tunai total ataupun tunai bertahap (tunai dalam 3 bulan) ataupun dengan menggunakan KPR (Kredit Pemilikan Rumah), yaitu dengan sistem angsur perbulan dan biasanya Bank menyarankan 30\% dari gaji konsumen.

4. Proses KPR (Kredit Pemilikan Rumah)

Proses KPR ini terdiri dari pengumpulan syarat-syarat KPR, proses penilaian baik agunan maupun perhitungan analisa kelayakan konsumen dalam membayar angsuran KPR sampai dengan munculnya persetujuan KPR dari bank. Pihak developer akan mengawal proses KPR karena sangat erat kaitannya dengan kepastian pembayaran, pembangunan rumah dan serah

7 I Made Erwan Kemara, A.A. Gede Agung Dharma Kusuma dan I Ketut Westra. “Tanggung Jawab Hukum Notaris Terhadap Akta Jual Beli Hak Milik Atas Tanah Yang Dibuatnya Ditinjau Dari Undang-Undang Nomor 30 Tahun 2004 Tentang Jabatan Notaris." Kertha Semaya: Journal Hukum 1, no.9 (2013), 1.

8 Made Ara Denara Asia Amasangsa dan I Made Dedy Priyanto. "Perjanjian Pengikatan Jual Beli (PPJB) Dalam Transaksi Peralihan Hak Atas Tanah Dan/Atau Bangunan." Kerta Semaya: Journal Hukum 1, no.1 (2019), 8. 
terima rumah yang kurang lebih membutuhkan waktu selama 2 (dua) minggu.

5. Uang Muka atau DP (Down Payment)

Pembayaran uang muka biasanya 2 atau 3 minggu setelah tanda jadi diterima. Uang muka yang harus dibayarkan oleh konsumen kepada PT. Restu Property adalah $30 \%$ dari harga rumah.

6. Pembangunan

Setelah proses KPR sudah disetujui serta uang muka atau DP (Down Payment) sudah diterima, maka pembangunan sudah mulai dilaksanakan oleh PT.Restu Property dan akan memakan waktu tergantung dari besaran unit rumah.

7. Serah Terima

Setelah pembangunan unit telah rampung 100\% maka sudah siap untuk melakukan serah terima ke pembeli. Pihak developer biasanya akan memberikan masa retensi selama 3 (tiga) bulan setelah serah terima dilakukan. Masa retensi adalah waktu yang pihak developer (pengembang) berikan terhadap keluhan-keluhan mengenai kondisi rumah. Pada masa retensi, apabila terdapat kerusakan mengenai bangunan dan kondisi rumah maka masih menjadi tanggung jawab pihak developer (pengembang) yang dalam hal ini adalah PT.Restu Property.

8. Akta Jual Beli

Akta jual beli adalah peralihan hak hukum atas tanah dan bangunan. Hal ini dilakukan di Notaris atau Pejabat Pembuat Akta Tanah. Tentunya sertifikat yang dulunya atas nama penjual atau developer akan beralih dan diatasnamakan ke konsumen. AJB (Akta Jual Beli) mengandung kewajiban pembayaran pajak. AJB dapat dilakukan sebelum serah terima rumah apabila skema pembayaran melalui KPR dengan KPR Inden. Perbedaan KPR Inden dengan KPR biasa adalah pencairan KPR yang dapat dilakukan secara bertahap sebelum bangunan dimulai.

9. Pencairan KPR

Pembuatan akta jual beli dan pembayaran pajak-pajaknya akan menjadi dasar untuk pencairan KPR oleh pihak developer (pengembang). Dalam pencairan KPR, konsumen berada dibawah ikatan kredit oleh Bank pemberi KPR di hadapan Notaris yang ditunjuk oleh pihak Bank. Pencairan KPR tidak harus menunggu bangunan 100\% jadi. Dengan KPR Inden, pihak developer dapat mencairkan sebagian nilai KPR.

Adapun sebelum melakukan suatu perjanjian, KUHPerdata mengatur ketentuan mengenai syarat sahnya suatu perjanjian yang diatur dalam Pasal 1320 KUHPerdata, yakni:

1. Tercapainya kata sepakat bagi mereka yang mengikatkan diri. Kata sepakat tersebut tidak boleh disebabkan karena adanya kekhilafan, paksaan, dan penipuan.

2. Cakap untuk membuat suatu perikatan artinya orang tersebut menurut hukum dapat melakukan perbuatan hukum. Seperti orang yang sudah dewasa, tidak dibawah pengampuan tidak cacat mental.

3. Suatu hal tertentu, hal ini berarti perjanjian harus menentukan jenis objek yang akan diperjanjikan. 
4. Suatu sebab atau causa yang halal, perjanjian yang dibuat tersebut tidak boleh bertentangan dengan perundang-undangan, kesusilaan dan ketertiban umum.

Pelaksanaan perjanjian jual beli rumah di PT. Restu Property ini merupakan perjanjian jual beli rumah yang didasarkan pada kesepakatan terlebih dahulu. Kesepakatan tersebut dilakukan dengan tidak adanya paksaan dan tidak ada penipuan. Apabila dikaji dari syarat sahnya perjanjian, maka perjanjian jual beli rumah ini telah memenuhi syarat subjektif dari ketentuan Pasal 1320 KUHPerdata. Sedangkan syarat objektif dari pasal ini, yang pertama yaitu suatu hal tertentu. Mengenai hal tertentu yang dimaksudkan ini adalah objek yang diperjanjikan tersebut adalah objek yang diperbolehkan. Dalam pelaksanaan perjanjian jual beli ini, objeknya adalah rumah. Jadi objek yang diperjanjikan tersebut telah memenuhi unsur objektif yang pertama. Selanjutnya, terhadap syarat objektif yang kedua adalah suatu sebab atau causa yang halal. Berdasarkan faktanya, perjanjian yang dibuat oleh PT. Restu Property dengan konsumen telah memenuhi unsur sebab yang halal. Dengan kata lain bahwa perjanjian jual beli rumah yang dibuat itu tidak bertentangan dengan perundang-undangan, kesusilaan dan ketertiban umum. Dengan demikian, maka dapat dikatakan bahwa pelaksanaan perjanjian jual beli rumah di PT. Restu Property adalah perjanjian yang sah menurut hukum. Walaupun perjanjian tersebut dibuat secara dibawah tangan, tetap memenuhi "ketentuan syarat sahnya perjanjian sebagaimana tercantum dalam Pasal 1320 KUHPerdata". ${ }^{9}$ Oleh sebab itu, pelaksanaan perjanjian di PT. Restu Property telah sesuai dengan syarat subjektif dan objektif perjanjian dan telah mengacu pada ketentuan Pasal 1320 KUHPerdata.

\subsection{Akibat Hukum Pembatalan Perjanjian Jual Beli Rumah Secara Sepihak Oleh Konsumen di PT. Restu Property}

PT. Restu Property adalah perusahaan yang bergerak dibidang property. Perusahaan ini telah banyak menyelesaikan proyek perumahan. Sampai saat ini, perusahaan ini sedang menyelesaikan proyeknya yang berada di Pesiapan, Tabanan. Perumahan ini diberi nama Graha Pesiapan. Perumahan Graha Pesiapan memiliki 22 unit rumah. Rumah ini mulai dipasarkan dan beberapa rumah sudah mulai terjual.

Berdasarkan fakta di lapangan, pada bulan Januari Tahun 2018, calon pembeli yang menginginkan rumah yang berada di Graha Pesiapan tersebut, secara kebetulan yang tersisa hanya 2 unit rumah saja dan akhirnya pembeli pun memilih rumah nomor 11 dan akhirnya mulailah melakukan kelengkapan untuk memulai pembayaran uang muka/ DP (Down Payment) yang sudah disepakati kedua belah pihak yaitu sebesar 30\% (tiga puluh persen) dari harga yang telah di sepakati. Setelah 2 bulan pembeli melakukan pembayaran uang muka, tiba-tiba pembeli mengatakan bahwa pembeli tidak jadi untuk membeli rumah tersebut dan meminta agar uang mukanya dikembalikan. Pembatalan dilakukan karena pembeli membutuhkan uang tersebut untuk anaknya bersekolah dan suami dari si pembeli tidak setuju. Pembatalan perjanjian tersebut dilakukan sepihak dan yang melakukan pembatalan adalah dari pihak pembeli.

9 Komang Calvin Krisna Dwipa dan Ni luh Gede Astariyani. "Pembatalan Tiket Hotel Online Secara Sepihak Oleh Pihak Agoda. “Kertha Semaya: Journal Hukum 2, no.9 (2019), 7. 
Pembatalan perjanjian ini, tentunya "menimbulkan akibat hukum bagi masingmasing pihak termasuk perjanjian yang telah disepakati sebelumnya"10. Akibat hukum yang dimaksud adalah akibat yang ditimbulkan dari pembatalan perjanjian jual beli rumah atau property tersebut. Menurut Syarifin, akibat hukum adalah "segala akibat yang terjadi dari segala perbuatan hukum yang dilakukan oleh subyek hukum terhadap obyek hukum atau akibat-akibat lain yang disebabkan karena kejadian-kejadian tertentu oleh hukum yang bersangkutan telah ditentukan atau dianggap sebagai akibat hukum". ${ }^{11}$ Berdasarkan uraian tersebut, untuk dapat mengetahui telah muncul atau tidaknya suatu akibat hukum, maka yang perlu diperhatikan adalah "adanya perbuatan yang dilakukan oleh subyek hukum terhadap obyek hukum atau terdapat akibat tertentu dari suatu perbuatan, yang mana akibat itu telah diatur oleh hukum. Adanya perbuatan yang seketika dilakukan bersinggungan dengan pengembanan hak dan kewajiban yang telah diatur dalam hukum (undang-undang)" ${ }^{12}$

Perbuatan hukum yang dilakukan oleh pihak PT. Restu Property dengan pembeli terhadap satuan rumah, dimana terdapat akibat hukum tertentu dari suatu perbuatan yang mana akibat hukum itu telah diatur oleh undang-undang. Selanjutnya, adanya perbuatan yang seketika dilakukan bersinggungan dengan pengembanan hak dan kewajiban yang telah diatur dalam perundang-undangan. Timbulnya hak dan kewajiban dari pembeli dan PT. Restu Property, merupakan akibat dari perbuatan hukum jual beli rumah antara PT. Restu Property dengan pembeli (konsumen).

Dalam Pasal 1338 KUHPerdata dinyatakan bahwa "Semua perjanjian yang dibuat secara sah berlaku sebagai undang-undang bagi mereka yang membuatnya". ${ }^{13}$ Pengertian pasal ini, mengartikan bahwa perjanjian itu dibuat oleh para pihak dan harus ditaati oleh para pihak pula. Dengan demikian, perjanjian itu juga diakhiri oleh para pihak. Jadi para pihaklah yang mengakhiri perjanjian itu (bukan sepihak). Pada prinsipnya, suatu perjanjian tidak dapat dibatalkan oleh sepihak, karena dengan adanya pembatalan tersebut, tentunya akan menimbulkan kerugian bagi pihak lainnya.

Pembatalan perjanjian hanya dapat dilakukan apabila diketahui adanya kekhilafan ataupun paksaan dari salah satu pihak ketika membuat perjanjian. Kekhilafan dan paksaan merupakan alasan yang dapat membatalkan perjanjian. Selain itu juga penipuan yang dilakukan oleh satu pihak terhadap pihak yang lainnya dalam membuat perjanjian, dapat dijadikan sebagai alasan untuk dapat dibatalkannya suatu perjanjian secara sepihak oleh salah satu pihak. Sesuai dengan Pasal 1320 KUH Perdata suatu perjanjian yang tidak didasarkan kepada syarat subjektif perjanjian, maka perjanjian tersebut dapat dibatalkan.

Pembatalan perjanjian tersebut hanya membawa para pihak pada keadaan semula yaitu keadaan sebelumnya para pihak baik pembeli maupun PT. Restu Property dianggap tidak pernah melakukan atau mengadakan perjanjian diantara mereka. Dengan demikian jelaslah bahwa suatu perjanjian hanya dapat dibatalkan secara sepihak oleh salah satu pihak apabila tidak memenuhi syarat sah subjektif dari suatu

10 Bagus Julio Suroso dan Desak Putu Dewi Kasih. “Kajian Yuridis Perbuatan Melawan Hukum Akibat Pemutusan Perjanjian Sewa-Menyewa Secara Sepihak Yang Dilakukan Oleh Direksi PT. Bali Unicorn. "Kertha Semaya: Journal Hukum 2, no.1 (2014), 5.

11 Pipin Syarifin, Pengantar Ilmu Hukum, (CV. Pustaka Setia, Bandung, 2019), 18.

12 Lukman Santoso,Teori Hukum dan Teknik Pembuatan Kontrak Kerja Sama dan Bisnis, (Setara Press, Malang,2016), 128.

13 Dewa Ayu Febryana Putra Nuryanti dan Putu Gede Arya Sumertayasa. " Peran dan Fungsi Pemerintah dalam Hubungan Industrial. “Kertha Semaya: Journal Hukum 2, no.8 (2018), 7. 
perjanjian. Pembatalan tersebut hanya dapat dilakukan dengan mengajukannya kepada pengadilan ataupun dengan pembelaan atau gugatan pihak yang akan membatalkan perjanjian.Sedangkan terhadap perjanjian yang dibatalkan secara sepihak oleh pembeli tanpa alasan yang sah, dapat diajukan tuntutan kepada pihak yang membatalkannya selama perjanjian tersebut telah berlangsung. Sebaliknya apabila pembatalan secara sepihak tersebut terjadi sebelum adanya pelaksanaan perjanjian maka pembatalan itu hanya membawa pada keadaan semula yaitu keadaan yang dianggap tidak pernah terjadi perjanjian.

PT. Restu Property selaku developer (pengembang) pernah mengalami pembatalan perjanjian secara sepihak yang dilakukan oleh pembeli (konsumen). Hal ini tentunya menimbulkan kerugian bagi pihak developer (PT. Restu Property). Kerugian tersebut sangat berpengaruh pada penjualan unit rumah. Dalam hal ini, rumah yang telah dipasarkan atau di promosikan dinyatakan telah terjual. Oleh sebab itu, rumah yang terjual itu tidak dipasarkan lagi oleh PT. Restu Property selaku pengembang. Dengan demikian, apabila ada konsumen yang ingin membeli rumah tersebut tidak diperbolehkan karena dianggap telah terjual. Sehingga, PT. Restu Property mengalami kerugian materiil. Seharusnya, rumah tersebut dapat saja dijual kepada pihak lain atau pembeli yang lain tapi tidak bisa karena telah diberikan uang muka terlebih dahulu.

Secara etika dan moral, "pembatalan ini tentunya merupakan perbuatan yang sangat tidak etis atau tidak sesuai dengan nilai-nilai etika dan moral dalam masyarakat" ${ }^{14}$ Sehubungan dengan itu, menurut Jro Dompol (berdasarkan wawancara pada hari Kamis tanggal 15 September 2020 pukul 11.00 Wita) selaku saksi dalam pembuatan perjanjian mengatakan bahwa "perbuatan pembatalan sepihak itu dikatakan perbuatan yang menyimpang dari etika dan moral. Dikatakan menyimpang, karena perbuatan tersebut sangat merugikan pihak PT. Restu Property baik dari segi materiil dan immaterial. Disamping itu, perbuatan tersebut mengandung unsur itikad tidak baik". Sehingga, akibat yang ditimbulkan sangatlah besar. Selain itu, perbuatan tersebut tidak memperdulikan akibat yang ditimbulkan kepada pihak dari PT. Restu Property, hanya mementingkan pihak pembeli.

Sehubungan dengan kerugian tersebut, pembatalan perjanjian yang dilakukan oleh pihak pembeli ini tentunya membawa kerugian bagi pihak developer. Berdasarkan hasil wawancara pada hari Kamis tanggal 15 September 2020 pukul 10.30 Wita dengan Ibu Ni Putu Artatik selaku direktur PT. Restu Property, lebih lanjut mengemukakan bahwa kerugian yang dialami oleh pihak developer dikarenakan rumah telah dibangun tetapi karena ada pembatalan secara sepihak dari pihak konsumen, maka developer memerlukan waktu lagi untuk mencari konsumen lain yang hendak membeli rumah tersebut dan juga membutuhkan waktu yang lama untuk mengembalikan biaya uang muka yang telah dipergunakan untuk membangun rumah yang sebelumnya telah disepakati. Dengan demikian, pembatalan perjanjian yang dilakukan oleh pihak pembeli secara sepihak ini tidak diperbolehkan oleh Pasal 1338 KUHPerdata. Sehingga perjanjian jual beli rumah tersebut pada dasarnya tidak bisa dibatalkan oleh masingmasing pihak karena sebelumnya telah terjadi kesepakatan. Apabila terjadi pembatalan perjanjian secara sepihak, maka akibat hukum yang ditimbulkan adalah perjanjian tersebut tetap berlaku bagi pihak yang membuatnya yaitu pihak PT. Restu Property dan pembeli. Sedangkan akibat moral yang ditimbulkan adalah pembeli sebagai pihak yang

14 Ida Ayu Putu Krisna Yanthi dan I Wayan Novy Purwanto. “Analisis Hukum Pembatalan Perjanjian Sewa Menyewa Kebaya Di Kota Denpasar."Kertha Semaya: Journal Hukum 7, no.12 (2019), 5. 
membatalkan perjanjian jual beli itu harus menunggu pihak yang bersedia membeli rumah tersebut atau dengan kata lain, pihak pembeli harus menunggu rumah itu laku terlebih dahulu. Selain akibat hukum, pembatalan ini menimbulkan akibat moral bagi para pihak. Akibat moral itu berupa pembeli harus sanggup menunggu rumah itu laku. Jadi akibat moral yang ditimbulkan adalah kewajiban masa tunggu bagi pihak pembeli sampai ada pihak pembeli berikutnya. Masa tunggu ini diberlakukan agar pihak PT. Restu Property dapat mengembalikan uang muka yang diminta oleh pembeli yang membatalkan perjanjian tersebut.

\section{Kesimpulan}

Pelaksanaan perjanjian jual beli rumah pada PT. Restu Property tahapannya meliputi pembayaran booking fee atau tanda jadi, pemilihan desain bangunan, menentukan cara pembayaran yang dapat dilakukan dengan cara tunai atau dengan $\mathrm{KPR}$, pembayaran uang muka atau DP, dilanjutkan dengan pembangunan rumah. Setelah rumah selesai dibangun dilakukan serah terima rumah dan pembuatan Akra Jual Beli (AJB), berdasarkan hal tersebut apabila pembayaran dilakukan dengan KPR maka pencairan KPR dapat dilakukan. Sedangkan, akibat hukum terhadap pembatalan perjanjian sepihak yang dilakukan oleh konsumen kepada PT. Restu Property adalah perjanjian dapat dibatalkan tanpa kewajiban bagi pihak developer untuk mengembalikan uang muka atau DP yang telah dibayarkan oleh konsumen. Upaya penyelesaian yang dilakukan adalah pihak developer dan konsumen membuat kesepakatan baru di hadapan Notaris mengenai pengembalian uang muka atau DP yaitu uang muka akan dikembalikan sebesar 50\% dari yang telah dibayarkan setelah rumah yang batal di beli mendapatkan konsumen baru yang telah membayar uang muka atau DP.

\section{DAFTAR PUSTAKA}

\section{Buku}

Heryy, Kamaroesid Tata Cara Pendirian dan Pengelolaan Badan Usaha Milik Desa, (Mitra Wacana Media, Bogor, 2016).

Marzuki, Peter Mahmud, Penelitian Hukum Edisi Revisi, (Predana Media Group,Jakarta,2010).

Pipin Syarifin, Pengantar Ilmu Hukum, (CV.Pustaka Setia,Bandung,2019).

Lukman Santoso, Teori Hukum dan Teknik Pembuatan Kontrak Kerja Sama dan Bisnis, (Setara Press, Malang, 2016).

\section{Jurnal}

Komang Bagus Try Permana dan A.A. Istri Ari Atu Dewi." Tugas- Tugas Badan Perlindungan Konsumen Nasional." Kertha Semaya: Journal Ilmu Hukum 2, no.1 (2017): 5.

Liberty Sinaga dan I.B Surya Dharma Jaya. “ Pembatalan Perjanjian Jual Beli Online Secara Sepihak Oleh Lazada.CO.ID. "Kerta Semaya: Journal Ilmu Hukum 2, no.2 (2014): 6.

I Made Erwan Kemara, A.A. Gede Agung Dharma Kusuma dan I Ketut Westra. “Tanggung Jawab Hukum Notaris Terhadap Akta Jual Beli Hak Milik Atas Tanah Yang Dibuatnya Ditinjau Dari Undang-Undang Nomor 30 Tahun 2004 Tentang Jabatan Notaris." Kertha Semaya: Journal Hukum 1, no.9 (2013): 1. 
Made Ara Denara Asia Amasangsa dan I Made Dedy Priyanto. "Perjanjian Pengikatan Jual Beli (PPJB) Dalam Transaksi Peralihan Hak Atas Tanah Dan/Atau Bangunan." Kerta Semaya: Journal Hukum 1, no.1 (2019): 8.

Komang Calvin Krisna Dwipa dan Ni luh Gede Astariyani. "Pembatalan Tiket Hotel Online Secara Sepihak Oleh Pihak Agoda. "Kertha Semaya: Journal Hukum 2, no.9 (2019): 7.

Bagus Julio Suroso dan Desak Putu Dewi Kasih. “Kajian Yuridis Perbuatan Melawan Hukum Akibat Pemutusan Perjanjian Sewa-Menyewa Secara Sepihak Yang Dilakukan Oleh Direksi PT. Bali Unicorn. "Kertha Semaya: Journal Hukum 2, no.1 (2014): 5.

Dewa Ayu Febryana Putra Nuryanti dan Putu Gede Arya Sumertayasa. " Peran dan Fungsi Pemerintah dalam Hubungan Industrial. "Kertha Semaya: Journal Hukum 2, no.8 (2018): 7.

Ida Ayu Putu Krisna Yanthi dan I Wayan Novy Purwanto. "Analisis Hukum Pembatalan Perjanjian Sewa Menyewa Kebaya Di Kota Denpasar." Kertha Semaya: Journal Hukum 7, no.12 (2019): 5.

\section{Ketentuan Perundang-undangan}

Undang-undang Dasar Negara Republik Indonesia Tahun 1945.

Kitab Undang-Undang Hukum Perdata

\section{Website}

Anonim. Apakah Kuasa Dalam PPJB Termasuk Dalam Kategori Kuasa Mutlak?. http:/ / m.propertykita.com/ (diakses September 22 ,2020).

Realty Real Estate Agents, Apa Yang Harus Anda Perhatikan Ketika Sudah Setuju Dengan Harga Property, http:/ / www.kebayoranrealty.com/ (diakses September 22,2020).

Fathia Azkia, Begini Cara Menggugat Pengembang Nakal, https://www.rumah.com/beritaproperti/ (diakses September 22,2020). 